\title{
Transport in the Aftermath of COVID-19: Lessons Learned and Future Directions
}

\author{
Robert Earley ${ }^{1}$, Peter Newman ${ }^{2}$ \\ ${ }^{1}$ EQ Consulting (Beijing) Ltd., Beijing, China \\ ${ }^{2}$ Curtin University, Perth, Australia \\ Email: rjearley@eqconsult.cn,p.newman@curtin.edu.au
}

How to cite this paper: Earley, R. and Newman, P. (2021) Transport in the Aftermath of COVID-19: Lessons Learned and Future Directions. Journal of Transportation Technologies, 11, 109-127. https://doi.org/10.4236/jtts.2021.112007

Received: December 14, 2020

Accepted: February 23, 2021

Published: February 26, 2021

Copyright $\odot 2021$ by author(s) and Scientific Research Publishing Inc. This work is licensed under the Creative Commons Attribution International License (CC BY 4.0).

http://creativecommons.org/licenses/by/4.0/ (c) (i) Open Access

\begin{abstract}
This paper is a review of the impact on transport in the Asian region where enforced lockdowns and transport reductions have come with real human costs in the areas of economic development and access to jobs, society and services from various perspectives including urban planning and transport, economy, GHG and air pollutant emissions and gender as some of the areas of focus in the Sustainable Development Goals. Transportation systems with a high level of planning, flexible modes of transport and good communication with the public have proved more resilient than others. Furthermore, digital infrastructure has proven to be a key transport solution through this crisis. Data collection and real-time analysis have proven that their time has come to be effective in urban planning and transport management. Digital infrastructure is also driving online shopping and urban delivery services that allow people seeking to be socially distant to access daily necessities in a fast and relatively inexpensive manner. Making use of new global data sets and computing techniques can help cities and countries to plan better. Developing countries will need to improve their ability to gather relevant data from public and private sources and furthermore use the data to achieve more resilient, sustainable transportation. Achieving Sustainable Development Goals will require a reprioritization of funding and efforts to ensure that countries are building optimized infrastructure that provide transport and mobility services with minimal financial burdens including new leapfrog transit systems.
\end{abstract}

\section{Keywords}

COVID-19, Asia-Pacific, Transportation Impacts, Pandemic Recovery, Transport Resiliency

\section{Introduction}

Global policy makers have been preparing for a global pandemic for decades. In 
December 2019, the SARS-CoV2 coronavirus started spreading around the world and one year later, had impacted every country on Earth. The disease, now known as "coronavirus disease of 2019" (COVID-19), with its ability to spread in populations quickly and undetected before appearing as an outbreak, has changed transportation in developed and developing countries alike. This paper summarizes its impact on Asian nations and assesses its potential to change transport patterns into the future based on the Intergovernmental 13th Regional Environmentally Sustainable Transport Forum in Asia organized by the United Nations Center for Regional Development (UNCRD) in November 2020 [1].

As of December 2020, China was one of the least impacted countries and with Chinese airlines reporting that that domestic travel had nearly returned to normal levels. Chinese cities are again faced with traffic jams and full subways. While this return to "normal" in China indicates hope for global recovery to business as usual, the challenges for a shift towards sustainable transport are no less than before.

This paper introduces the good experiences and best practices of countries across Asia as they respond to the transport challenges posed by this pandemic which does not respect political or economic boundaries-not just to return to normal, but to continue to push for transport systems that serve the public, serve economies, and respect environmental and social objectives.

\section{COVID-19's Impact on Transport in Asia}

The COVID-19 pandemic has affected the entire world more dramatically than any other specific event since the end of the second world war. This disease, which is thought to be primarily transmitted via airborne vectors, including on diesel particulates [2], passes silently and invisibly through populations and can cause outbreaks that overwhelm medical services, resulting in public fear of leaving home and government imposition of lock-down policies to try to stem its spread. The impact on the global economy and society has been dramatic. Besides the illness and loss of life (Table 1), trade in merchandise for 2020 is expected to be $9.2 \%$ lower than in 2019 globally, and $4.5 \%$ lower in Asia [3]. Real GDP could fall 4.4\% globally from 2019 in 2020, 1.7\% in emerging and developing Asia, $10.3 \%$ in India and $3.4 \%$ in ASEAN. P.R. China might be the only major economy in the world to see growth at $1.9 \%$ in 2020 [4] - an outcome far worse than the 2008-09 financial crisis. Significantly for economies in Asia, $100 \%$ of tourist destinations globally have severe travel restrictions in place, meaning international tourism receipts will decline by USD 0.9 to 1.17 trillion compared to 2019, indicating a reduction of international tourist arrivals in Southeast Asia by $74 \%$ and Northeast Asia of $86 \%$ [5].

Globally, passenger air transport fell to nearly zero in April, 2020 and as of October, 2020 had recovered barely $20 \%$ of the same amount of traffic compared to a year earlier. In Asia, seat capacity on airlines fell nearly $80 \%$ from January 2020 to April and is still only $60 \%$ of what it had been a year earlier [7]. While 
Table 1. Confirmed cases of COVID-19 and related deaths in Asia and the Pacific Region as of 4 November 2020 [6].

\begin{tabular}{|c|c|c|c|c|c|}
\hline Country & $\begin{array}{l}\text { Confirmed } \\
\text { Cases }\end{array}$ & Deaths & Country & $\begin{array}{l}\text { Confirmed } \\
\text { Cases }\end{array}$ & Deaths \\
\hline Afghanistan & 41,728 & 1544 & Maldives & 11,796 & 38 \\
\hline Bangladesh & 412,647 & 5983 & Mongolia & 350 & 0 \\
\hline Bhutan & 358 & 0 & Myanmar & 55,804 & 1307 \\
\hline Cambodia & 292 & 0 & Nepal & 179,614 & 1004 \\
\hline China & 92,045 & 4746 & Fiji & 34 & 2 \\
\hline $\begin{array}{l}\text { Democratic People's } \\
\text { Republic of Korea }\end{array}$ & 0 & 0 & Pakistan & 336,260 & 6849 \\
\hline India & $8,313,876$ & 123,611 & $\begin{array}{l}\text { Papua New } \\
\text { Guinea }\end{array}$ & 597 & 7 \\
\hline Indonesia & 418,375 & 14,146 & Philippines & 387,161 & 7318 \\
\hline Iran & 637,712 & 36,160 & Sri Lanka & 11,744 & 23 \\
\hline $\begin{array}{c}\text { Lao People's } \\
\text { Democratic Republic }\end{array}$ & 24 & 0 & Thailand & 3804 & 59 \\
\hline \multirow[t]{2}{*}{ Malaysia } & 34,393 & 263 & Timor-Leste & 30 & 0 \\
\hline & & & Viet Nam & 1203 & 35 \\
\hline
\end{tabular}

aviation might be the most visibly impacted form of transport in the global media, the effects of COVID-19 on local and regional transport have the greatest impacts on the daily lives of people and businesses around the world. Cities without effective pandemic or disaster planning everywhere have had to enforce massive restrictions on public transport in the hopes of avoiding transmission of the virus. Freight and logistics are undergoing unprecedented changes, not only due to tightly closed international and domestic borders, but also because people, less willing to leave their homes, require goods delivered to their doors. Logistics systems have had to adapt to border blockages, testing and tracking of vehicle operators, and improved tracking and tracing of vehicles and shipments.

The impact of COVID-19 on transport cannot be underestimated. The question that remains is, what will it take for transport to recover, and when it recovers, how can it be improved to be more resilient and to serve people, their communities, and their economies in a more sustainable and equitable way?

\section{Impacts of COVID-19 on Achieving Sustainable Development Goals in Transport in Asia and the Pacific}

The 2030 Agenda for Sustainable Development states that "sustainable transport systems, along with universal access to affordable, reliable, sustainable and modern energy services, quality and resilient infrastructure, and other policies that increase productive capacities, would build strong economic foundations for all countries." [8]. Sustainable, resilient and equitable transport systems are key to 
achieving near all the Sustainable Development Goals (SDGs): directly, to five targets on road safety, energy efficiency, sustainable infrastructure, urban access and reduced fossil fuel subsidies; and additionally to targets on agricultural productivity, air pollution, access to safe drinking water, sustainable cities, reduction of food loss, climate change adaptation and climate change mitigation [9]. This section is an update on some of the impacts to achievement of these goals, namely through examination of emissions, infrastructure planning, public transport implementation, freight and logistics, road safety, and a feature on the gender impacts of COVID-19's impact on transportation in Asia.

\subsection{Emissions and Transport through the Pandemic}

The impact of COVID-19 on GHG emissions from the transport sector has been, at certain points of the pandemic, the largest of all major sectors of the global economy. In March and April, ground transport, plus international aviation and shipping accounted for more than half of emission reductions compared to 2019 [10]. Even by October 2020, although total emission reductions compared to 2019 were smaller than earlier in the year, transport was still the biggest contributor to those reductions, indicating the huge decrease in transport activity during the pandemic period.

\subsection{Impacts on Infrastructure Planning}

The COVID-19 pandemic had swift and brutal impacts on both the operation of current transport and energy systems globally, as well as plans for the development of new transport systems in both developed and developing countries. The severe economic slowdown experienced by the global economy has caused many countries to delay or reconsider their plans for new development and likewise has caused financial organizations to take pause as previously economically viable projects might now take significantly longer to produce a return. Global value chains surrounding infrastructure development have broken down as raw materials, logistics and skilled labor and other contributors are no longer available to implement projects. In the short term, governments are forced to put their infrastructure plans on hold to an extent.

While these changes seem like an insurmountable challenge, they should also be seen as an opportunity to further implement the SDGs in transport. In the long term, there is an opportunity to re-think priorities and turn further towards a decarbonization agenda. Scarce resources may be better allocated to wider sidewalks, pedestrianized streets, dedicated bike lanes, electric scooter pathways or car-free zones now that the health and safety benefits of such investments have become clearer to residents and governments alike. Furthermore, investment in digital infrastructure that allows people and companies to work from home, plan their trips better, and reduce their transport demand are suddenly more important than material- and land-intensive roadways and other car-oriented infrastructure [11]. 


\subsection{Public Transport}

The impact on the development of, and public perception of public transport has been massive. Even as public transport is the primary means of daily mobility for millions of people across Asia and the Pacific, perceived and real risks of becoming infected by coronavirus has made passengers wary of getting on crowded buses, trains or subways. Reduction in capacity has even made it impossible for many people to get to work, undermining the public perception of reliability of public transport when crises occur. Where past, passengers were willing to tolerate poor or crowded public transport services, now passengers are legitimately worried about becoming sick from being in a confined space. This need not be a negative impact on the further development of public transport though. With the public focused on the quality of public transport, there are new demands for higher quality transport, reformed business models, and better services such as contactless payment and better ventilation [12]. Governments are now faced with the challenge of supporting their public transit systems and legitimate concerns of their populations now give them the remit to re-think their current strategies.

A global survey of experts indicated that modal shift away from public transport during the pandemic period has been dramatic [13]. In the Republic of Korea, experts surveyed expected a modal shift of $94.4 \%$ from public transport to personal car, and only 5.6\% expected a shift to bicycle. $33.3 \%$ expected a shift to walking ${ }^{1}$. India, on the other hand, say $46.4 \%$ of experts expecting to see a shift from public transport to car, $50 \%$ to walking and $50 \%$ to motorcycle. In all, $42.7 \%$ of experts in the survey were observing a shift to lower carbon modes of transport, while $45.2 \%$ were expecting a shift to higher carbon mode, indicating a need for policy makers to focus on ensuring that public transport remains a safe and trusted form of transport.

\subsection{Freight and Logistics}

The freight and logistics sector-for dry goods as well as for food-are similarly facing huge challenges but also opportunities to become more sustainable. The moment internal and external borders closed, governments needed to take fast measures to ensure that key daily goods such as food and other necessities could be made available to residents in locked-down areas. Domestically, it was truck drivers who became some of the first people to be frequently tested for coronavirus in China, and with their health tracking mobile phone apps, and application of Personal Protective Equipment (PPE) were able to continue to bring freight to locked down areas. The impact of COVID-19 on international freight has not been so easy. Air freight has been significantly reduced due to heavy impacts on the business models of airlines that make use of both passenger freight and cargo freight to balance their business models. For some time, flights full of

${ }^{1}$ Multiple choices were allowed in the survey. 
PPE delivered to various countries and locales were flown at a premium cost. Now, the air frieight sector is awaiting the arrival and production of a viable COVID-19 vaccine in order to secure revenue.

Sea freight has also been heavily affected. At the beginning of the pandemic, ships were not welcome to arrive at port for fear of crew infecting on-shore staff and residents. Even today, many ships' crews are not allowed to disembark from their ships without a 14-day quarantine. Given that many crews are staffed by citizens of Bangalesh, Myanmar, Philippines and other Asian countries, many people were stranded at sea, unable to return home to their families. Recently, countries have started to recognize that different origin countries have different risk levels in terms of crews infecting on-shore staff and residents when they arrive at port. The Commerce Ministry of India for example, has requested that the Shipping Ministry reduce the quarantine period for vessels arriving from China to be reduced from 14 days to 7 days, both in order to better facilitate trade, but also based on lower risk potential of ships from China. Furthermore, India faces a shortage of containers because ships are not able to come to port as quickly as needed.

Slower border crossings provide a risk to sustainable development of crossborder trade. However, the development of track-and-trace technologies across borders offers an opportunity to open up borders in the long term, and avoid waits at borders that result in resource waste, fuel consumption from idling trucks, and other severe inefficiencies that come about from drivers needing to wait for border crossing approvals. Track-and-trace systems that integrate between the private sector and governments could result in more seamless supply chains through cross-border freight for all sorts of goods, and in particular food.

\subsection{Impacts on Road Safety}

Road safety has been negatively impacted by COVID-19 in the Western Pacific Region [14]. Significantly, although fewer people are traveling, more people are using private forms of transport including bicycles, e-bikes and scooters on the roads, and popular walking areas used by pedestrians are being closed or blocked by pandemic-management infrastructure. In some cases, road safety policy enforcement has been suspended, and with emergency services overwhelmed by COVID-19 cases, response time to road accidents has been slowed, meaning a higher rate of serious injury or death when collisions occur.

\subsection{Gender and Transport in the COVID-19 Era: Impacts on Women}

Asia and the Pacific region is home to one billion women of reproductive age and is estimated to have 50 million pregnant women [15]. The COVID-19 pandemic, like many other crises, is having a disproportionate impact on women and girls. Economic opportunities, safety and security, and voice and leadership in decision-making are being affected when businesses close, personal freedoms are restricted, and community interaction is reduced. When transport systems 
are less available or completely unavailable for periods of time, women are faced with significant challenges and can face unhealthy, inconvenient, uncomfortable and even dangerous situations from which they have no route of escape.

In many countries in Asia and the Pacific region, travel restrictions due to COVID-19 response as well as other natural phenomenon such as monsoon floods have impacted women's and girl's access to sexual and reproductive health services. Lack of transport service has a particular impact on women on rural areas, as well as women of minority groups who face language and cultural barriers. Solutions such as telehealth services for psychological support and social media for accessing young people have been established across the region, but are dependent on strong communication infrastructure. Training of midwives in local areas has also been important to ensuring healthy deliveries of babies in rural and less accessible areas during these times of poor transport services. In Lao PDR, for example, between February and July 2020, 270 midwives were trained on reproductive, maternal, newborn, child and adolescent health services and over half a million people have received family planning services. Midwives in Papua New Guinea have been trained with the "Safe Delivery App" that provides them with direct access to evidence-based and up-to-date clinical guidelines on COVID-19 in pregnancy, infection prevention and control, and basic emergency obstetric and neonatal care. Remote psychosocial support is being delivered for women and girls to uphold their dignity and wellbeing, ensure safe births, and help girls stay in school [16].

In many places, women make up a large proportion of essential workers-including health workers, and also do much of the unpaid caregiving and domestic work at home, which is amplified with children at home from school due to social distancing. In many cases, women could be tasked with facilitating home or e-learning while children are not at school, further reducing their ability to go to jobs and undertake domestic work. Women facing particular challenges would be those caring for the elderly or disabled, particularly when other care givers cannot be present due to social distancing, and women cannot leave home to acquire daily necessities [17].

Women's businesses and the industries that they work in have been some of the hardest hit-particularly due to a reduction in urban and inter-urban transport, such as in food service, retail, hospitality and entertainment. 50 per cent of women in Asia and the Pacific have reported drops in working time compared to men (35\%) [18]. Globally, 40 percent of all employed women (510 million women) work in hard-hit sectors compared to 36.6 percent of all men. Domestic workers, 80 per cent of whom are women, are heavily impacted when they are unable to travel to their work places. It has been reported in Samoa and TimorLeste that businesses such as vegetable stands and other small shops typically operated by women are closing down because there is simply less foot traffic through markets due to less access. Reduction in transport services globally are affecting export-oriented businesses where women are typically employed. In 
Bangladesh, the ready made garment sector is a key employment sector for women. Yet due to lock downs and reduced access to shopping centres in western markets, as well as due to reduced access to logistics, these companies are experienced dramatically lower demand [19].

While women are likely to be highly impacted by COVID-19 due to their existing economic and social constraints, in reality data being collected about the economic fallout of the pandemic is not being reported on a gender disaggregated basis, and therefore it is difficult to gain transparency in real-time on the challenges that women and girls are facing both economically and in terms of transport [20].

While solutions to these challenges are few at this time, some countries are beginning to look at how digital infrastructure can help women to gain some stability through difficult economic times, reducing their need to leave the home and allowing them to hold electronic bank accounts and receive and make payments electronically thus allowing them to build new business models, access microfinance, and securing their assets in safe accounts, with mobile financial accounts becoming a focus in countries such as Bangladesh [21]. Digital infrastructure is also important for women in rural areas as they can use online learning to improve agricultural practices, understand demand for cash crops, arrange for logistics and access markets remotely [22].

\section{Best Practices in Asia: Examples and Outcomes for Pandemic Management and Post-Pandemic Recovery}

Experience with epidemic diseases in some Asian countries, such as SARS, prepared some countries well for the outbreak of COVID-19 in 2020. Many countries in Asia made a fast and heavy response to COVID-19 in the hopes of avoiding the widespread transmission of the disease altogether rather than having to manage the disease long into the future. Unfortunately, the first step toward avoidance has little to do with transport-or, that is to say, has to do with shutting down transport in and between cities. A survey of transport experts around the world in April and May 2020 indicated that "China" (as defined in the paper) was by far most prepared with guidelines and contingency plans in the areas of bus systems, rail transit systems, taxis, aviation, passenger maritime and other systems compared to other countries around the world [23]. South Korea also had favourable preparations in these areas, and the outcomes are clear. Today (December 2020), these countries are operating nearly free of local transmission of COVID-19 despite the global pandemic that continues.

\section{Lockdowns across Asia}

The lockdown in the city of Wuhan, P.R. China, where the first major COVID-19 outbreak was observed, serves as the most salient example, where the entire city was locked down, with limited transport services for any purpose. Residents were given limited opportunities to leave their homes to shop for basic supplies, 
and in many cases, supplies were delivered to the gates of residential compounds so that residents would not need to travel outside their nearby areas. During this time, logistics for food delivery and hospital building were prioritized above all other uses, resulting in the construction of a 1000 bed emergency hospital within 10 days, and for the most part, residents being served with fresh food for cooking [24], all in the epicentre of this crisis. Meanwhile, all trains and flights to and from the city were cancelled from 23 January 2020 for 11 weeks, and road transport was severely limited [25]. Figure 1 highlights the impact of the lockdown on transport in Wuhan in comparison to the lockdown in Beijing (Figure 2).

This lockdown was eventually extended to many cities in China so as to avoid transmission and to allow existing infections to play out before they spread to other people and places. While the lockdown was not pursued early enough to prevent the spread of the virus globally, it was eventually effective for stemming the out-of-control expansion of the epidemic across China. While this intensity of lockdown seemed draconian at the time, and some argued that it was more intense than necessary, the result is that as of November 2020, there are nearly no active COVID-19 infections across P.R. China, let alone in the city of Wuhan, and no community infections have been reported in most cities in China for over 90 days-with imported cases quickly isolated and treated [28]. Today, Wuhan has no transport restrictions, and all modes of transport have returned to near-normal levels as residents tend to maintain high compliance with face mask wearing and other social distancing rules. Table 2 outlines the status of lockdowns and other social distancing strategies in Asian countries as of time of writing.

Lockdowns in other Chinese cities were not as severe as in Wuhan, as they did not have the initial uncontrolled infection period to deal with. In cities such as

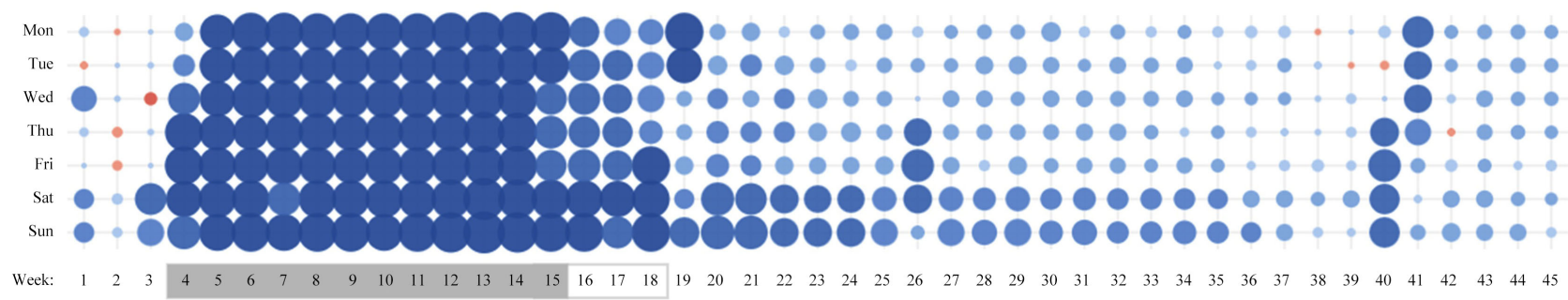

Figure 1. 2020 Weekly road congestion levels in Wuhan compared to 2019 [26].

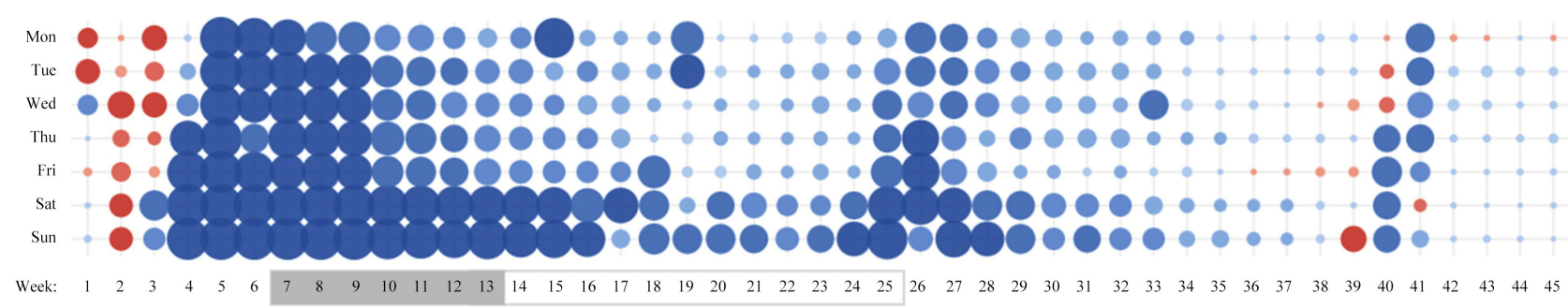

Figure 2. 2020 Weekly road congestion levels in Beijing compared to 2019 [27]. 
Table 2. Transport restrictions adopted due to COVID-19 as of October 2020. [29] [30] and inputs from the Intergovernmental 13th Regional Environmentally Sustainable Transport Forum in Asia (November 2020) [31].

\begin{tabular}{|c|c|c|c|c|}
\hline & Domestic Travel & Urban Public Transit & International Transport & Other measures \\
\hline Australia & Require closing & None to limited measures & $\begin{array}{l}\text { Total border closure } \\
\text { except New Zealand }\end{array}$ & $\begin{array}{l}\text { Partial school closures, stay at home } \\
\text { requirements in high-risk areas }\end{array}$ \\
\hline Azerbaijan & Require closing & None to limited measures & Total border closure & \\
\hline Bangladesh & None to limited measures & Recommended closing & Ban on high-risk regions & \\
\hline Bhutan & Require closing & Recommended closing & Total border closure & \\
\hline Brunei Darussalam & Recommended closing & None to limited measures & Mandatory quarantine & Schools open with measures in place \\
\hline Cambodia & None to limited measures & None to limited measures & Mandatory quarantine & $\begin{array}{l}\text { Gradual reopening of schools, all } \\
\text { entertainment closed. }\end{array}$ \\
\hline Fiji & Night curfew in effect & & & $\begin{array}{l}\text { Schools open with measures, } \\
\text { workplaces at } 50 \% \text { capacity }\end{array}$ \\
\hline Georgia & Recommended closing & None to limited measures & Total border closure & \\
\hline India & Require closing & Require closing & Ban on high-risk regions & \\
\hline Indonesia & Recommended closing & $\begin{array}{l}\text { Staged opening of public } \\
\text { transit }\end{array}$ & Total border closure & $\begin{array}{l}\text { Schools open in low-risk areas, } \\
\text { workplaces open with measures }\end{array}$ \\
\hline Japan & None to limited measures & None to limited measures & $\begin{array}{l}\text { Ban on high-risk region } \\
\text { arrivals }\end{array}$ & \\
\hline Kazakhstan & Recommended closing & Require closing & Total border closure & \\
\hline the Lao PDR & None to limited measures & None to limited measures & Ban on high-risk regions & \\
\hline Malaysia & $\begin{array}{l}\text { Restriction on high-risk } \\
\text { areas }\end{array}$ & None to limited measures & Total border closure & $\begin{array}{l}\text { Workplaces open except for } \\
\text { entertainment, }\end{array}$ \\
\hline Mongolia & None to limited measures & None to limited measures & Total border closure & \\
\hline Myanmar & Require closing & Require closing & Ban on high-risk regions & \\
\hline Nepal & Require closing & Require closing & Total border closure & \\
\hline New Zealand & None to limited measures & None to limited measures & Total border closure & \\
\hline Papua New Guinea & None to limited measures & None to limited measures & $\begin{array}{l}\text { Quarantine arrivals with } \\
\text { GPS tracking }\end{array}$ & \\
\hline $\begin{array}{l}\text { the People's } \\
\text { Republic of China }\end{array}$ & Opened by 10 October & $\begin{array}{l}\text { Required face masks and } \\
\text { use of contact tracing apps }\end{array}$ & $\begin{array}{l}\text { Ban on high-risk regions, } \\
\text { mandatory quarantines }\end{array}$ & \\
\hline the Philippines & Recommended closing & Recommended closing & Total border closure & Age-based stay-at-home requirements \\
\hline $\begin{array}{l}\text { The Republic of } \\
\text { Korea }\end{array}$ & $\begin{array}{l}\text { Generally open except } \\
\text { high-risk areas }\end{array}$ & None to limited measures & $\begin{array}{l}\text { Ban on high-risk regions } \\
\text { with mandatory } \\
\text { quarantine }\end{array}$ & \\
\hline Singapore & None to limited measures & None to limited measures & Quarantine arrivals & \\
\hline Sri Lanka & None to limited measures & None to limited measures & Total border closure & \\
\hline Thailand & Recommended closing & Recommended closing & $\begin{array}{l}\text { Mandatory quarantine, } \\
\text { certain travellers welcome }\end{array}$ & \\
\hline Timor-Leste & None to limited measures & None to limited measures & Ban on high-risk regions & \\
\hline Uzbekistan & Require closing & Recommended closing & Total border closure & \\
\hline Vanuatu & None to limited measures & Recommended closing & Total border closure & \\
\hline Viet Nam & Screening in place & Recommended closing & Total border closure & \\
\hline
\end{tabular}


Beijing, Shanghai and Guangzhou, public transit was severely limited during the lockdown period with fewer scheduled trips, reduced routes and increased time required for sanitization between trips. All staff on public transit were given protective clothing, and entrance to all stations was controlled with a requirement to display a track-and-trace app indicating that passengers had not been near any high-risk areas in the previous 14 days. Temperature checking for fever was also checked at all station entry points, as well as all buildings and residential compounds. Persons found to have fever were not permitted entry to public transit and were referred to hospitals for treatment. Even after restrictions were lifted, it is generally expected to wear a face mask in crowded places such as on public transport, and compliance rates are high [32].

Capacities of subway and other public transit systems were adjusted in Chinese cities. In Guangzhou, maximum load capacity was reduced to half, and increased to 70\% in April, with full service restored in May [33]. During the worst parts of the pandemic, Beijing metro introduced an online reservation system for metro station access with the aim of managing peak traffic and station crowding. From 6:30 am to 9:30 am on weekdays, riders were required to reserve entry to the subway using a mobile phone application (Figure 3) [34].

Taipei City has also had a successful approach to dealing with COVID-19. After the first reported case of COVID-19 on 21 January, 2020, the metro responded
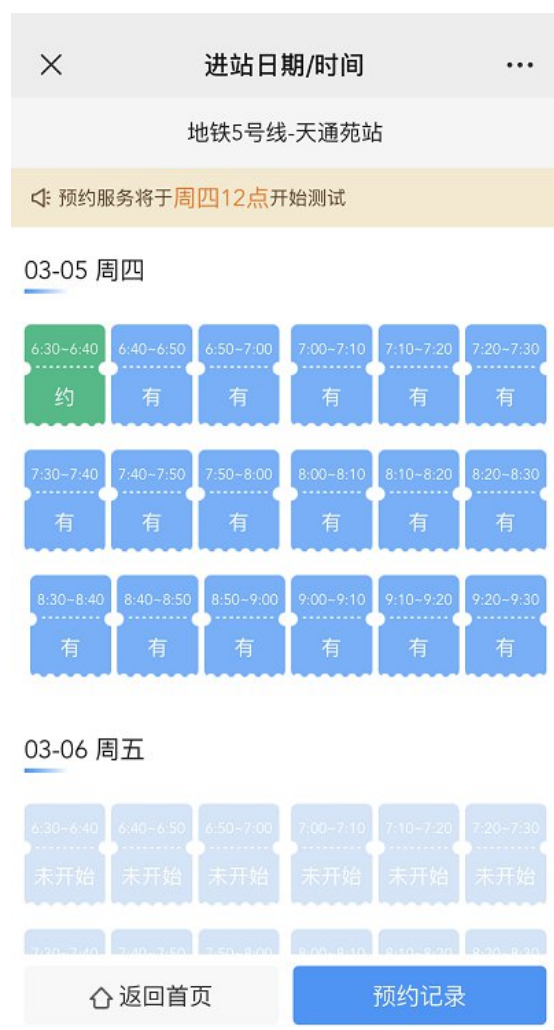

Figure 3. A Screen capture from the Beijing Metro mobile phone app station entry reservation system. Users may choose a time indicated in blue to enter the station indicated [35]. 
by implementing its epidemic preparedness plan. By 24 January, all front-line staff wore masks; by 30 January, train disinfection and cleaning had increased, and by 3 February, all passengers were encouraged to wear masks while on board. The mayor of Taipei city was filmed at station platforms and trains to give confidence to residents about taking the subway. By 5 April, a requirement to wear masks was in place, and infrared scanners were set up at high volume stations. 10,000 passengers were intercepted for not wearing masks, and were reminded of the rule. Failure to act on reminders would result in the equivalent of a USD 500 fine. Additionally, Taipei City agreed with other nearby cities to implement common policies.

The combination of fast response and public messaging meant that the impact on Taipei's transit network was less than on many others around the world [36].

The policies implemented by countries in Asia and the Pacific have important impacts on the way that residents travel in their cities. Google has produced a series of COVID-19 Community Mobility Reports based on mobile phone data from Android phones that compare peoples' movement on an anonymous basis compared to 2019. The analytical tool categorizes transport destinations into six categories: Retail and Recreation, Supermarket and pharmacy, Parks, public transport, Workplaces and Residential. These free tools are available online and allow policy makers to understand what the impact of their policies are on the behaviour of residents in their countries. Clearly, different countries, based on their local conditions have different responses. Not every country has seen reduced patronage on public transit, nor reduced presence at workplaces, indicating the needs of local people for transport as well as the intensity of the policies implemented.

\section{Rebuilding Better from COVID-19}

While countries face intense economic challenges, there are opportunities to make use of public funds to maintain employment and meanwhile significantly improve transport infrastructure and systems to become more sustainable for the future. The Online Platform on Sustainable and Resilient Recovery from COVID-19 initiative is led by the Ministry of the Environment of Japan, is supported by the UNFCCC and managed by the Institute for Global Environmental Strategies (IGES), providing a comprehensive listing of initiatives countries are taken to recover sustainably (Table 3 ).

Recovery and building back better freight policy in particular have been a focus of research by UNESCAP through the COVID-19 pandemic. A survey conducted by the organization noted priorities of governments and experts as follows [38]:

- Protect transport workers

- Adapt to changes in transport market behavior

- Strengthen cross-border connectivity

- Support economic growth, including job creation 
Table 3. Sustainable transport actions by countries as part of a COVID-19 recovery plan (Author analysis based on [37]).

\begin{tabular}{cc}
\hline Action & Countries \\
\hline Electric vehicle promotion and charging infrastructure & $\begin{array}{c}\text { Bangladesh, P.R. China, } \\
\text { Indonesia, Nepal, Pakistan }\end{array}$ \\
Electric vehicle promotion in rural areas & Bangladesh, P.R. China \\
Renewable electricity-Electric vehicle integration & Bangladesh, Nepal \\
Cycling programs and infrastructure & the Philippines, P.R. China \\
Integrated transport planning & P.R. China \\
Rural road improvements & Bhutan \\
Zero emission shipping & Japan, P.R. China \\
High emission diesel vehicle replacement & P.R. China \\
Transport energy efficiency improvements & Indonesia \\
Financial assistance to transport workers & the Philippines \\
Public utility vehicle modernization & the Philippines \\
\hline
\end{tabular}

- Increase the resilience of freight transport

- Improve digitalization of transport services

- Integrate decarbonization and sustainable transport.

These categories are meant to help countries move towards improved connectivity in Asia-Pacific that is:

1) Digitalized - with smart infrastructure, paperless trade, and intelligent transport/logistics;

2) Resilient-taking advantage of multimodality, operational connectivity, and transport facilitation at borders; and,

3) Green/decarbonized-making better use of rail, waterborne transport, energy efficiency and renewable energy.

Financial institutions are generally increasing their support of these actions as part of Net Zero outcomes that are being defined as necessary for investment. Very low interest rates are also now available and the era of building back with the Paris Agreement and the SDG's as the agenda, is now much clearer [39]. However, nations must work out what this means in their infrastructure programs. The opportunities in using leapfrog technology for transit systems is becoming more obvious in the post-Covid period [40].

\section{Conclusions}

The COVID-19 pandemic is a once-in-a-century challenge to all of humanity. This disease which forces people to isolate from one another and which currently has no cure, is not just a health issue-it has turned into an economic disaster of the real economy, where both demand and supply have decreased significantly thus impacting peoples' jobs, incomes and access to public services. Households and governments alike find themselves having to make very difficult eco- 
nomic decisions just to keep afloat, with major impacts on transportation in Asia.

Social distancing has had a disastrous effect on the transport systems of countries around the world. People, scared to be close to one another, are avoiding public transport, especially in places where PPE such as face masks are not available. Urban lock-downs are keeping people at home, away from their jobs and access to daily necessities. The knock-on effect is that public transit and other public infrastructure that relies on user fees is suddenly without revenue, putting services and investors at risk. While countries have found ways to maintain food and basic goods logistics through the pandemic, global trade has slowed down significantly, disrupting the movement of ships, airplanes, and the operation of ports. Reduction of transport services in rural areas also has important impacts. Agricultural systems are put at higher risk if they are unable to move their goods to market, or unable to sell their goods at market because customers are no longer coming out to shop. Women and girls are particularly affected when these transport systems shut down, much more likely to lose economic opportunities, access to sexual and reproductive services, and access to school.

There is also a new recognition of the weakness for sustainable transport finance as economies have fewer fiscal resources to allocate. As it was noted at the Intergovernmental $13^{\text {th }}$ Regional Environmentally Sustainable Transport Forum in Asia (10-11 November, 2020), climate finance has not benefitted the transport sector, and investment models such as private-public partnerships demonstrate clear risks to investors if they suddenly have no revenue because of a lack of transport resiliency. Models for risk sharing, insurance and other that they are enforced. Best practices to date are to adapt the transport supply-in the correct volumes and focused on the areas that need it the most; scaling and reinforcing cleaning and disinfection; supplying appropriate PPE to staff and passengers where necessary; ensuring that staff and passengers comply with health regulations; increasing the level of natural ventilation in vehicles and public spaces, increasing digitalization and IT tools to better monitor operations; anticipating the number of travelers and providing real-time response so as to avoid crowding; implementing contactless payment systems; and providing staff and customers with regular and transparent communications [41]. Trackless trams are an evolving system in Asia that is technologically advanced, appropriate for mid-sized cities, flexible because it does not require track installation, able to use renewable energy in its electric drive train.

\subsection{Digital Infrastructure Is Key to Transport Improvement and Resilience}

The pandemic has made clear that digital infrastructure is of eminent importance in building up a modern, resilient economy that can continue to operate without as much dependence on transport of people, and is key to consider in urban and national transport plans. Digital infrastructure is key for implementing work-at-home policies of companies, online education, and the online con- 
sumer economy. A continued push by all countries-both in rural and urban areas-to implement strong digital infrastructure is key to ensuring access to services, and will continue to be important even after the present pandemic is over. Digital infrastructure, while improving access to services, can help to reduce the fiscal cost of public services in the long term and enable all residents to enjoy better public services, access to financial services, and if they desire, to stay closer to their homes and families to develop their local communities. During pandemic times, digital infrastructure is key for identifying outbreaks through social tracing, but in normal times, such infrastructure can also be used to facilitate better community planning, improved transport services and better urban logistics and e-commerce. Digital infrastructure also has multiple benefits for women and families as it improves access to online banking and electronic payment so that women's income can be secured. Digital infrastructure is also important for facilitating trade and improving freight and logistics services. Consumers and businesses alike require more and better information about the status of shipments. Route and timing optimization for freight shipments and better market data transparency can help businesses to produce and provide products and services to markets where they are wanted or needed. With more transparency on imports, exports and domestic trade, governments can better optimize freight transport infrastructure and planning.

\subsection{Non-Motorized Transport as a Healthy, Sustainable and Resilient Plan for All}

Finally, although non-motorized transport (NMT) is not always realistic for longdistance urban and rural travellers, providing safe, accessible facilities for NMT remains essential for facilitating safe and healthy lifestyles of residents. Fresh air and healthy lifestyles significantly decrease the chances of COVID-19 infection as well as nearly all other types of disease, and in times of crisis, non-motorized transport may be the only mode of transport available for many people, and is required in a resilient transport scenario. Furthermore, as urban logistics make use of smaller or even non-motorized vehicles, increased infrastructure to ensure delivery worker safety on roads.

In these extraordinary times, countries and cities are struggling fiscally to provide even essential services and economic development opportunities. Although some financial resources are available at low interest rates, governments around the world are doing more with less until global systems improve; it is essential therefore that resources of all types-fiscal, physical and operational-be optimized. Meanwhile, data is proliferating with the use of mobile phones and the mobile internet that can be harnessed by the public and private sectors alike to improve transport services and provide greater evidence for the financial institutions that invest in transport projects. Coming out of the pandemic, it is essential that governments learn to use these resources to make evidence-based decisions about infrastructure and investment to make the very best transport systems for their countries and cities in the post-COVID recovery period. 


\section{Future Work}

The pandemic is still not over and the possibility that the coronavirus will be with humanity in the long-term is a risk that will continue to inform research, policy decisions, and socio-economic development in developed and developing nations alike. It is key that responses and best practices of countries continue to be monitored, that countries dramatically improve data collection and data processing capabilities in order to make sense of the large data sets that are increasingly available to them, and finally to continue to push towards sustainable, resilient transport systems that protect the public from infectious disease while facilitating their day to day lives. Future research can focus on the role of big data in decision-making for pandemic response in the transport systems of developing countries in Asia, and on the co-benefits of pandemic resilience and climate resilience of sustainable transport infrastructure and practices.

\section{Conflicts of Interest}

The authors declare no conflicts of interest regarding the publication of this paper.

\section{References}

[1] United Nations Department of Economic and Social Affairs-Sustainable Development (2020) Concept Note and Provisional Programme.

https://sdgs.un.org/sites/default/files/2021-01/UNCRD 13th\%20EST\%20Forum Fi nal\%20Concept $\% 20$ Note $\% 20 \% 26 \% 20$ Provisional\%20programme- $\% 2011 \% 20$ Nov $\%$ 202020.pdf

[2] Gudka, S., Armstrong, B. and Newman, P. (2020) Cutting Diesel Exhaust Could Lessen COVID Spread in Cities.

https://www.scientificamerican.com/article/cutting-diesel-exhaust-could-lessen-cov id-spread-in-cities/

[3] World Trade Organization (2020) Trade Shows Signs of Rebound from COVID-19, Recovery Still Uncertain.

https://www.wto.org/english/news e/pres20 e/pr862 e.htm

[4] International Monetary Fund (2020) World Economic Outlook, October 2020: A Long and Difficult Ascent.

https://www.imf.org/en/Publications/WEO/Issues/2020/09/30/world-economic-outl ook-october-2020

[5] United Nations World Tourism Organization (2020) International Tourism and COVID-19. https://www.unwto.org/international-tourism-and-covid-19

[6] World Health Organization (2020) COVID-19 Explorer. https://worldhealthorg.shinyapps.io/covid/

[7] International Civil Aviation Organization (2021) Effects of Novel Coronavirus (COVID19) on Civil Aviation: Economic Impact Analysis. https://www.icao.int/sustainability/Documents/COVID-19/ICAO Coronavirus Ec on Impact.pdf

[8] United Nations General Assembly (2015) Transforming Our World: The 2030 Agenda for Sustainable Development.

https://www.un.org/ga/search/view doc.asp?symbol=A/RES/70/1\&Lang=E 
[9] SLOCAT Partnership (n.d.) Transport Targets in the Sustainable Development Goals. https://slocat.net/transport-targets-sustainable-development-goals/

[10] United Nations Environment Programme (2020) Emissions Gap Report 2020. https://www.unep.org/emissions-gap-report-2020

[11] Abadie, R. (2020) COVID-19 and Infrastructure: A Very Tricky Opportunity. https://blogs.worldbank.org/ppps/covid-19-and-infrastructure-very-tricky-opportu nity

[12] Cabrera, R (2020) Many Filipinos Want Better Transport Solutions from Gov't Amid the Pandemic-Study.

https://www.onenews.ph/many-filipinos-want-better-transport-solutions-from-gov -t-amid-the-pandemic-study

[13] Hayashi, Y. (2020) Transport in the Aftermath of COVID-19: Lessons Learned and Future Directions: a Case of Japan. In: Intergovernmental 13 th Regional Environmentally Sustainable Transport Forum in Asia United Nations Center for Regional Development, Nagoya.

[14] Lukaszyk, C. (2020) Changing the Course of Asia's Transport Sector through Partnership for Safer Journeys in the Aftermath of COVID-19. In: Intergovernmental 13th Regional Environmentally Sustainable Transport Forum in Asia, United Nations Center for Regional Development, Nagoya.

[15] World Health Organization (2020) Women of Reproductive Age (15-29 Years) Population (Thousands).

https://www.who.int/data/maternal-newborn-child-adolescent-ageing/indicator-ex plorer-new/mca/women-of-reproductive-age-(15-49-years)-population-(thousands)

[16] United Nations Population Fund (2020) Asia and the Pacific Region COVID-19 Situation Report No. 9.

https://www.unfpa.org/sites/default/files/resource-pdf/APRO COVID-19 Regional Sitrep 9 October.pdf

[17] Mercado, L., Naciri, M. and Mishra, Y. (2020) Women's Unpaid and Underpaid Work in the Times of COVID-19: Move towards a New Care-Compact to Rebuild a Gender Equal Asia.

https://asiapacific.unwomen.org/en/news-and-events/stories/2020/06/womens-unp aid-and-underpaid-work-in-the-times-of-covid-19

[18] Azcona, G.A.-C. (2020) From Insights to Action: Gender Equality in the Wake of COVID-19.

https://www.unwomen.org/-/media/headquarters/attachments/sections/library/pub lications $/ 2020 /$ gender-equality-in-the-wake-of-covid-19-en.pdf?la=en \&vs $=5142$

[19] Lopez-Acevedo, G., Kokas, D., Robertson, R. and Medeiros, D.C. (2020) How Decline in Demand for Apparel Affects Poor Women in Bangladesh.

https://blogs.worldbank.org/endpovertyinsouthasia/how-decline-demand-apparel-a ffects-poor-women-bangladesh?cid=pov tt_poverty en ext

[20] UN Women (2020) COVID-19 and Its Economic Toll on Women: The Story behind the Numbers.

https://www.unwomen.org/en/news/stories/2020/9/feature-covid-19-economic-imp acts-on-women?utm source $=$ dlvr.it\&utm medium $=$ facebook

[21] Brixi, H. and Dixon, A. (2020) Innovation and Sound Policies Are Critical to Protect People during the Crisis.

https://blogs.worldbank.org/voices/innovation-and-sound-policies-are-critical-prot ect-people-during-crisis

[22] Decker, A., Van de Velde, P. and Montalvao, J. (2020) COVID-19: A Pivotal Mo- 
ment to Support Women Farmers.

https://blogs.worldbank.org/developmenttalk/covid-19-pivotal-moment-support-w omen-farmers

[23] Zhang, J.Y. and Hayashi, Y. (2020) Impacts of COVID-19 on the Transport Sector and Measures as Well as Recommendations of Policies and Future Research: Analyses Based on a World-Wide Expert Survey. https://papers.ssrn.com/sol3/papers.cfm?abstract id=3611806

[24] Ankel, S. (2020) A Construction Expert Broke Down How China Built an Emergency Hospital to Treat Wuhan Coronavirus Patients in Just 10 Days.

https://www.businessinsider.com/how-china-managed-build-entirely-new-hospitalin-10-days-2020-2

[25] Johns Hopkins Coronavirus Resource Center (2020) Hubei Timeline. https://coronavirus.jhu.edu/data/hubei-timeline

[26] TomTom International BV (2020) Wuhan Traffic. https://www.tomtom.com/en gb/traffic-index/wuhan-traffic/

[27] TomTom International BV (2020) Beijing Traffic. https://www.tomtom.com/en gb/traffic-index/beijing-traffic/

[28] Burki, T. (2020) China's Successful Control of COVID-19. The Lancet Infectious Diseases, 20, 1240-1241.

[29] Asian Development Bank (2020) COVID-19 and Transport in Asia and the Pacific: Guidance Note.

https://www.adb.org/sites/default/files/institutional-document/623426/covid-19-tra nsport-asia-pacific-guidance-note.pdf

[30] Benson, T.A. (2020) Oxford COVID-19 Government Response Tracker Regional Report-EAST ASIA PACIFIC 1-31 October 2020.

[31] United Nations Center for Regional Development (2021) Thirteenth Regional Environmentally Sustainable Transport (EST) Forum in Asia.

https://sdgs.un.org/sites/default/files/2021-01/UNCRD_13th\%20EST\%20Forum Fo rum\%20Summary\%20-\%20Final-Adopted-issued-without $\% 20$ formal\%20editing-12 \%20Jan\%202021.pdf

[32] Liu, D.Z., Xue, L.L. and Huang, T. (2020) 3 Ways China's Transport Sector Is Working to Recover from COVID-19 Lockdowns.

https://thecityfix.com/blog/3-ways-chinas-transport-sector-working-recover-covid19-lockdowns/

[33] Institute for Transport \& Development Policy (2020) How China Kept Transit Running During COVID-19.

https://www.itdp.org/2020/07/03/how-china-kept-transit-running-during-covid-19/

[34] xinhuanet.com (2020) Beijing Metro Pilots Peak Station Entry Reservations.

https://www.itdp.org/2020/07/03/how-china-kept-transit-running-during-covid-19/

[35] Beijing Subway (2020) Beijing Subway Reservation System Wechat Mini-App Screen Capture. https://webui.mybti.cn/\#/login

[36] Kamote, A. (2020) Taipei Metro's Successful COVID-19 Response. https://taipeiurbanism.com/taipei-metro-successful-covid-19-response/

[37] Ministry of the Environment of Japan (2020) Online Platform on Sustainable and Reslient Recovery from COVID-19.

[38] Ducrest, A.J. (2020) Regional Transport Cooperation in Asia and the Pacific. In: Intergovernmental 13th Regional Environmentally Sustainable Transport Forum in Asia, United Nations Center for Regional Development, Nagoya.

[39] Newman, P. (2020) COVID, CITIES and CLIMATE: Historical and Potential Tran- 
sitions for the New Economy Urban Science, 4, 32.

https://doi.org/10.3390/urbansci4030032

[40] Ndlovu, V. and Newman, P. (2020) How Can Developing Cities Leapfrog into the Future with a Technology Like Trackless Trams? Journal of Transportation Technologies, 10, 198-213. https://doi.org/10.4236/jtts.2020.103013

[41] International Association of Public Transport (2020) Public Transport Is COVIDSafe.

https://cms.uitp.org/wp/wp-content/uploads/2020/10/Policy-Brief-PTisCOVID-Saf e.pdf 